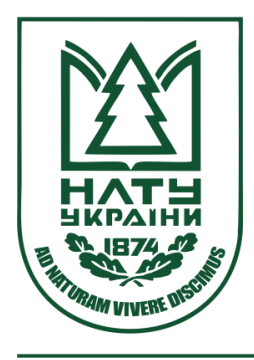

Науковий вісник НлтУ України Scientific Bulletin of UNFU

https://nv.nltu.edu.ua

https://doi.org/10.15421/40280415

$@ \bowtie$ Correspondence author

Article received 09.11.2018 p.

Article accepted 29.11.2018 p.

V. V. Melnyk

УДК 630.114:574(477.42)

melnyk_vika91@ukr.net

В. В. Мельник

Житомирський державний технологічний університет, м. Житомир, Украйна

\title{
СУЧАСНИЙ ВЕРТИКАЛЬНИЙ РОЗПОДІЛ ЦЕЗІЮ-137 У ГРУНТАХ СВІЖИХ БОРУ ТА СУБОРУ УКРАЇНСЬКОГО ПОЛІССЯ
}

\begin{abstract}
Проаналізовано сучасний розподіл ${ }^{137} \mathrm{Cs}$ у лісових грунтах різних типів лісорослинних умов Українського Полісся. Виявлено максимальні величини питомої активності радіонукліду у лісовій підстилці. За величиною питомої активності ${ }^{137} \mathrm{Cs}$ шари лісової підстилки свіжих борів і суборів можна розмістити у порядку зменшення: розкладений шар > напіврозкладений шар > сучасний опад. Найбільші значення питомої активності радіонукліду у мінеральній частині грунту встановлено у 0-4 см шарі гумусово-елювіального горизонту: у свіжих борах цей показник становив $1450^{ \pm 36}$ Бк/кг, у свіжих суборах $1187^{ \pm 31}$ Бк/кг. Із заглибленням у грунт виявлено поступове зменшення величин питомої активності ${ }^{137} \mathrm{Cs}$. Встановлено такий розподіл сумарної активності ${ }^{137} \mathrm{Cs}$ у грунтових горизонтах свіжих борів і суборів: в елювіальному - 8,5 і 15,8 \% від загальної активності радіонукліду у грунті; в ілювіальному - 9,1 та 7,4 \%; в ілювіальному піску - 6,7 \% і 10,7 \% та материнській породі - 2,1 та $1,8 \%$ відповідно. Загальний сумарний вміст ${ }^{137} \mathrm{Cs}$ у лісовій підстилці та гумусово-елювіальному горизонті становить у свіжих борах 73,6 \%, у суборах - 64,3\%. Частка сумарної активності ${ }^{137}$ Cs у лісовій підстилці становить $15,4 \%$ у свіжих борах та 22,5 \% у свіжих суборах. До нижніх шарів грунтового розрізу (12-88 см) мігрувало відповідно 26,4 та 35,7 \% від загального запасу радіонукліду у грунті.
\end{abstract}

Ключові слова: розподіл радіонуклідів; лісові грунти; питома активність ${ }^{137} \mathrm{Cs}$; сумарна активність; тип лісорослинних умов; лісова підстилка.

Вступ. Під час аварії на Чорнобильській АЕС лісові масиви акумулювали значну кількість радіонуклідів, які переважно затримались верхнім деревним ярусом рослинності. 3 часом, під впливом зовнішніх і внутрішніх факторів, відбулася їх міграція на поверхню грунту та поступове заглиблення у його товщу. Отже грунтовий покрив став своєрідним нагромаджувачем ${ }^{137} \mathrm{Cs}$ та першою ланкою у ланцюгу міграції радіонуклідів до інших компонентів лісових екосистем (Bulavik \& Zhuchenko, 1992; Krasnov et al., 2007).

Досліджуючи міграцію радіонуклідів у лісових грунтах вчені установили, що швидкість цього процесу залежить від багатьох факторів: гранулометричного та мінерального складу грунту, агрохімічних його характеристик (кислотності, вмісту органічних речовин та хімічних аналогів радіонуклідів, грунтової вологості), фiзичних та фізико-хімічних властивостей грунту, складу рослинного покриву лісових насаджень, кліматичних умов регіону (Kulikov, Molchanova \& Karavaeva, 1990; Shcheglov, et. al, 1996; Shcheglov, 1999). Окрім цього, встановлено, що важливу роль у перерозподілі радіонуклідів у грунтовому профілі відіграють потужність і склад лісової підстилки. 3'ясовано, що інтенсивність перерозподілу радіонуклідів у грунті залежить від зазначених характеристик лісової підстилки та наявності мохового покриву (Landin et al., 2011; Perevolotckii et al., 2007).
У наукових публікаціях констатовано, що лісова підстилка має значно більші значення питомої активності радіонукліду порівняно з мінеральними горизонтами грунту. Водночас, зіставляючи сумарний вміст ${ }^{137} \mathrm{Cs}$ у тих чи інших горизонтах грунту, було отримано протилежний результат. Науковці пояснили це низькою щільністю лісової підстилки (Boiko, 2012; Krasnov, 2015; Landin, 1993; Perevolotckii et al., 2007). Також дослідники зазначили, що істотний вплив на швидкість міграції ${ }^{137} \mathrm{Cs}$ у лісових грунтах мають екологічні умови зростання: багатство та вологість грунту (Krasnov, 1998; Siaskyi \& Stetsiuk 2001; Krasnov, 2016). Так, у бідних і більш вологих типах лісорослинних умов встановлено інтенсивніше заглиблення радіонуклідів у глибші шари грунту (Krasnov et al., 2015). Дослідники також з'ясували, що основна частина радіонуклідів сконцентрована у лісовій підстилці та у верхніх мінеральних шарах грунту (гумусово-елювіальний горизонт потужністю до 10 см) (Bondapenko \& Kononenko, 1995; Krasnov et al., 2015, 2016).

Треба зазначити, що за останні $10-15$ років у наукових публікаціях трапляються лише поодинокі дослідження, в яких розглянуто перерозподіл радіоактивних елементів у грунтах лісових екосистем. Водночас, як зазначено вище, грунти залишаються початковою ланкою у міграції радіоактивних елементів до численних їх компонентів. Враховуючи, що основним джерелом над-

Інформація про автора:

Мельник Вікторія Вікторівна, аспірант. Email: melnyk_vika91@ukr.net; https://orcid.org/0000-0002-3551-5085

Цитування за ДСтУ: Мельник В. В. Сучасний вертикальний розподіл цезію-137 у ґрунтах свіжих бору та субору Українського Полісся. Науковий вісник НЛТУ України. 2018, т. 28, № 10. С. 71-75.

Citation APA: Melnyk, V. V. (2018). Modern vertical distribution of cesium-137 in the soils of Fresh bors and subors of Ukrainian Polissia. Scientific Bulletin of UNFU, 28(10), 71-75. https://doi.org/10.15421/40281015 
ходження радіонуклідів у рослини є кореневе поглинання, виникає потреба вивчення сучасного вертикального перерозподілу ${ }^{137} \mathrm{Cs}$ у найпоширеніших лісових грунтах Українського Полісся, для майбутнього оцінювання його вмісту в різних компонентах лісових екосистем.

Об'скти та методика дослідження. Дослідження здійснювали у 2017 р. у Житомирському Поліссі на постійних пробних площах, розташованих у Народицькому лісництві ДП "Народицький СЛГ" (ППП № 1 та 2) (табл. 1). Мета наших досліджень - вивчили сучасний вертикальний розподіл ${ }^{137} \mathrm{Cs}$ у дерново-підзолистих грунтах найпоширеніших типів лісорослинних умов (свіжих борах і суборах) Українського Полісся. ППП закладали згідно з наявними методиками (ГОСТ 56-6983 "Площі пробні лісовпорядні. Метод закладки" і ОСТ 56-44-80 "Знаки натурні лісовпорядні і лісогосподарські. Типи, розміри і загальні технічні вимоги"). Лісові насадження на ППП були характерні для цих типів умов місцезростання.

Табл. 1. Таксаційна характеристика лісових насаджень на постійних пробних площ

\begin{tabular}{|c|c|c|}
\hline \multirow[t]{2}{*}{ Показник } & \multicolumn{2}{|c|}{$\begin{array}{c}\text { Таксаційна характеристика } \\
\text { лісових насаджень }\end{array}$} \\
\hline & ППП № 1 & ППП № 2 \\
\hline Квартал/виділ & $44 / 8$ & $10 / 30$ \\
\hline Тип лісорослинних умов & $\begin{array}{c}\text { свіжий бір } \\
\left(\mathrm{A}_{2}\right)\end{array}$ & $\begin{array}{l}\text { свіжий субір } \\
\left(\mathrm{B}_{2}\right)\end{array}$ \\
\hline $\begin{array}{l}\text { Щільність радіоактивного } \\
\text { забруднення грунту, кБк/м² }\end{array}$ & $266,5^{ \pm 11,8}$ & $422,8^{ \pm 24,3}$ \\
\hline Вік, років & 56 & 60 \\
\hline Склад насадження & $10 \mathrm{C}_{3}$ & $10 \mathrm{C}_{3}$ \\
\hline Середня висота, м & 16 & 18 \\
\hline Середній діаметр, см & 20 & 22 \\
\hline Клас бонітету & 2 & 1 \\
\hline Підріст & відсутній & поодинокий \\
\hline Підлісок & поодинокий & $\begin{array}{c}\text { чітко } \\
\text { виражений }\end{array}$ \\
\hline $\begin{array}{l}\text { Проективне покриття трав'яно- } \\
\text { чагарничкового ярусу, \% }\end{array}$ & $50-55$ & $70-75$ \\
\hline $\begin{array}{l}\text { Проективне покриття } \\
\text { мохового ярус, \% }\end{array}$ & $85-90$ & $85-90$ \\
\hline Асоціація & сосновий ліс & зеленомоховий \\
\hline Грунт & $\begin{array}{c}\text { дерново-під- } \\
\text { золистий пі- } \\
\text { щаний }\end{array}$ & $\begin{array}{l}\text { дерново-се- } \\
\text { редньопідзо- } \\
\text { листий, легко- } \\
\text { суглинковий }\end{array}$ \\
\hline
\end{tabular}

Грунтові розрізи закладали 3 дотриманням вимог проведення цих досліджень (Vedmid \& Raspopina, 2010), а опис грунтових розрізів виконували за загальноприйнятими методиками у грунтознавстві, грунтуючись на морфологічних ознаках грунту (потужність грунту та окремих його горизонтів, забарвлення, вологість, механічний (гранулометричний) склад, структура, складення, новоутворення та включення в грунт) (табл. 2) (Popupana, Nosko \& Kuzmicheva, 1981).

В усіх грунтових профілях відібрали зразки грунту для визначення питомої активності ${ }^{137} \mathrm{Cs}$ у генетичних горизонтах. Зразки грунту відбирали через кожні 4 см у десятиразовій повторності за всіма шарами генетичних горизонтів на глибину до 88 см. Поділ лісової підстилки здійснювали за ступенем мінералізації - сучасний опад, напіврозкладений та розкладений шари. Усі зразки висушували до повітряно-сухого стану, подрібнювали та гомогенізували. Вимірювання питомої активності ${ }^{137} \mathrm{Cs}$ в зразках здійснювали на сцинтиляційному гаммаспектрометричному приладі (GDM-20) із багатоканальним аналізатором імпульсів (AI). Статистичну обробку отриманих даних проводили за загальноприйнятими методами за допомогою прикладного пакету Microsoft Excel тa Statistica 10.0.

Табл. 2. Морфологічні ознаки грунтів у різних типах лісорослинних умов

\begin{tabular}{|c|c|}
\hline Свіжий бір $\left(\mathrm{A}_{2}\right)$ & Свіжий субір $\left(\mathrm{B}_{2}\right)$ \\
\hline $\begin{array}{l}\mathrm{H}_{0}-0-8 \text { см - складається зі } \\
\text { залишків сосни звичайної, зе- } \\
\text { лених мохів та трав'янистих } \\
\text { рослин; у нижній частині про- } \\
\text { низаний корінням рослин. }\end{array}$ & $\begin{array}{l}\mathrm{H}_{0}-0-10 \text { см - складається з } \\
\text { відмерлих решток сосни зви- } \\
\text { чайної, зелених мохів, } \\
\text { трав'яних рослин; у нижній } \\
\text { частині пронизаний корінням } \\
\text { рослин. }\end{array}$ \\
\hline $\begin{array}{l}\text { НЕ - 0-12 см - сірий, піща- } \\
\text { ний, свіжий, пухкий, прониза- } \\
\text { ний корінням рослин, перехід } \\
\text { поступовий за забарвленням }\end{array}$ & $\begin{array}{l}\text { НЕ - 0-12 см - темно-сірий, } \\
\text { свіжий, піщаний, рихлий, пе- } \\
\text { рехід поступовий за забар- } \\
\text { вленням, інтенсивно прониза- } \\
\text { ний корінням рослин }\end{array}$ \\
\hline $\begin{array}{l}\text { E - 12-16 см - світло-сірий, } \\
\text { піщаний, свіжий, рихлий, рід- } \\
\text { ко пронизаний корінням рос- } \\
\text { лин, перехід поступовий за } \\
\text { забарвленням }\end{array}$ & $\begin{array}{l}\text { Е - 12-24 см - світло-сірий, } \\
\text { свіжий, рихлий, супіщаний, } \\
\text { рідко пронизаний корінням } \\
\text { рослин, перехід поступовий за } \\
\text { забарвленням }\end{array}$ \\
\hline $\begin{array}{l}\mathrm{I} \text { - 16-36 см - світло-коричне- } \\
\text { вий, піщаний, свіжий, рих- } \\
\text { лий, перехід поступовий за } \\
\text { забарвленням }\end{array}$ & $\begin{array}{l}\text { I - 24-32 см - бурувато-ко- } \\
\text { ричневий, рихлий, свіжий, су- } \\
\text { піщаний, перехід поступовий } \\
\text { за забарвленням }\end{array}$ \\
\hline $\begin{array}{l}\text { PI-36-68 см - світло-жов- } \\
\text { тий, піщаний, рихлий, свіжий, } \\
\text { перехід поступовий за забар- } \\
\text { вленням }\end{array}$ & $\begin{array}{l}\mathrm{PI}(\mathrm{gl})-32-64 \text { см - світло- } \\
\text { жовтий, свіжий, щільний, лег- } \\
\text { косуглинковий пісок, перехід } \\
\text { різкий за забарвленням }\end{array}$ \\
\hline $\begin{array}{l}\text { P - 68... см - білий пісок, пі- } \\
\text { щаний, рихлий, свіжий }\end{array}$ & $\begin{array}{l}\text { P(gl) - 64... cм - білий пісок, } \\
\text { легкосуглинковий, щільний, } \\
\text { свіжий }\end{array}$ \\
\hline
\end{tabular}

Примітки: $\mathrm{H}_{0}$ - лісова підстилка; $\mathrm{HE}$ - гумусово-елювіальний горизонт; Е - елювіальний горизонт; I- ілювіальний горизонт; PI - ілювіальний пісок; PI(gl) - ілювіально-оглеєний горизонт; $\mathrm{P}$ - материнська порода; $\mathrm{P}(\mathrm{gl})$ - материнська порода оглеєна.

Результати дослідження та їх обговорення. У лісових грунтах свіжих борів і суборів спостерігались загальні закономірності щодо вертикального розподілу питомої активності ${ }^{137} \mathrm{Cs}$ у досліджуваних шарах (табл. 3). Встановлено, що максимальні значення величин питомої активності радіонукліду - у лісовій підстилці, що у всіх типах лісорослинних умов цей показник збільшується від верхньої до нижньої її частини.

Так, питома активність у свіжому бору розкладеного шару була в 1,9 раза більша, ніж напіврозкладеного шару та в 3 рази, ніж сучасного опаду; для свіжого субору такі відмінності становили - в 1,1 та 1,2 раза відповідно. Аналізуючи вміст ${ }^{137} \mathrm{Cs}$ між різними шарами лісової підстилки в умовах свіжого бору та субору можна стверджувати, що середні значення питомої активності у шарах лісової підстилки були досить різними, що підтверджують результати однофакторного дисперсійного аналізу: $\quad \mathrm{F}_{\text {факт. }}=979>\mathrm{F}_{(2 ; 29 ; 0,95)}=3,3$ та $\mathrm{F}_{\text {факт. }}=27>$ $\mathrm{F}_{(2 ; 29 ; 0,95)}=3,3$ відповідно. На підставі величин питомої активності ${ }^{137} \mathrm{Cs}$ шари лісової підстилки у всіх типах лісорослинних умов можна розмістити у порядку їх зменшення: розкладений шар > напіврозкладений шар > сучасний опад.

Мінеральна частина грунту характеризувалась значно меншими значеннями питомої активності ${ }^{137} \mathrm{Cs}$ порівняно $з$ лісовою підстилкою. Найбільші величини цього показника відзначено у гумусово-елювіальному горизонті (0-4 cм) з подальшим поступовим зменшенням в інших, більш глибоко розташованих горизонтах. Існування достовірної різниці між середніми значеннями питомої активності ${ }^{137} \mathrm{Cs}$ розкладеного шару лісової підстилки та 4-сантиметровому шарі гумусово-елювіального горизонту підтверджують результати однофак- 
торного дисперсійного аналізу на 95 \%-му довірчому рівні $\mathrm{F}_{\text {факт. }}=3354>\mathrm{F}_{(1 ; 19 ; 0,95)}=4,4-$ свіжий субір та $\mathrm{F}_{\text {факт. }}=1349>\mathrm{F}_{(1 ; 19 ; 0,95)}=4,4-$ свіжий бір. Аналізуючи розподіл ${ }^{137} \mathrm{Cs}$ у шарах гумусово-елювіального горизонту у свіжому суборі встановлено, що відмінності середніх значень у шарах становить між зразками, відібраними на глибині: 0-4 см - 4-8 cм - у 3 рази, 4-8 см - 8$12 \mathrm{~cm}-$ в 1,3 та $0-4$ см $-8-12 \mathrm{~cm}-$ у 4 рази; у свіжому бору - у 2, 1,1 та 2,2 раза відповідно. Отримані результати свідчать, що у свіжих суборах відбувається інтенсивніше вертикальне переміщення ${ }^{137} \mathrm{Cs}$ у гумусовоелювіальному шарі. За результатами однофакторного дисперсійного аналізу встановлено, що середні величини питомої активності шарів гумусово-елювіального горизонту, як свіжих борів, так і свіжих суборів, мають достовірну різницю, що підтверджується критерієм Фішера на 95 \%-му довірчому рівні: шар 0-4 см - 4-8 см $\mathrm{F}_{\text {факт. }}=293>\mathrm{F}_{(1 ; 19 ; 0,95)}=4,4$ та $\mathrm{F}_{\text {факт. }}=487>\mathrm{F}_{(1 ; 19 ; 0,95)}=4,4 ; 4$ $8 \mathrm{~cm}-8-12 \mathrm{~cm}-\mathrm{F}_{\text {факт. }}=5,9>\mathrm{F}_{(1 ; 19 ; 0,95)}=4,4$ та $\mathrm{F}_{\text {факт. }}=17,7>$ $\mathrm{F}_{(1 ; 19 ; 0,95)}=4,4 ; \quad 0-4 \mathrm{~cm}-8-12 \mathrm{~cm}-\quad \mathrm{F}_{\text {факт. }}=338>$ $\mathrm{F}_{(1 ; 19 ; 0,95)}=4,4$ та $\mathrm{F}_{\text {факт. }}=692>\mathrm{F}_{(1 ; 19 ; 0,95)}=4,4$.

Табл. 3. Розподіл питомої активності ${ }^{137} \mathrm{Cs}$ у лісових грунтах свіжого бору та субору Українського Полісся

\begin{tabular}{|c|c|c|c|c|}
\hline \multirow{2}{*}{ Шар грунту } & \multicolumn{2}{|c|}{ Питома активність } & \multicolumn{2}{|c|}{ Питома активність } \\
& ${ }^{137}$ С у свіжому бору & \multicolumn{2}{|c|}{ Сs у свіжому субору } \\
\cline { 2 - 5 } М & $\mathrm{m}$ & $\mathrm{M}$ & $\mathrm{M}$ \\
\hline Сучасний опад & 7047 & 160,7 & 14873 & 343,9 \\
\hline $\begin{array}{c}\text { Напіврозкла- } \\
\text { дений шар }\end{array}$ & 11481 & 179,4 & 17356 & 428,8 \\
\hline $\begin{array}{c}\text { Розкладений } \\
\text { шар }\end{array}$ & 22131 & 355,3 & 18498 & 582,3 \\
\hline НЕ 0-4 & 1450 & 36,0 & 1187 & 31,5 \\
\hline НЕ 4-8 & 729 & 85,2 & 397 & 17,1 \\
\hline НЕ 8-12 & 650 & 72,4 & 311 & 10,9 \\
\hline $12-16$ & 361 & 29,6 & 274 & 9,2 \\
\hline $16-20$ & 93 & 3,9 & 173 & 4,9 \\
\hline $20-24$ & 70 & 3,4 & 133 & 13,1 \\
\hline $24-28$ & 66 & 3,3 & 160 & 7,1 \\
\hline $28-32$ & 77 & 2,0 & 123 & 6,0 \\
\hline $32-36$ & 63 & 1,5 & 74 & 5,2 \\
\hline $36-40$ & 59 & 3,2 & 84 & 10,7 \\
\hline $40-44$ & 32 & 1,1 & 100 & 3,5 \\
\hline $44-48$ & 35 & 4,5 & 99 & 3,9 \\
\hline $48-52$ & 56 & 3,3 & 19 & 1,5 \\
\hline $52-56$ & 43 & 2,9 & 6 & 0,7 \\
\hline $56-60$ & 13 & 1,0 & 4 & 0,7 \\
\hline $60-64$ & 11 & 0,6 & 8 & 0,3 \\
\hline $64-68$ & 10 & 0,4 & 6 & 0,2 \\
\hline $68-72$ & 15 & 1,9 & 10 & 1,0 \\
\hline $72-76$ & 29 & 14,3 & 11 & 0,7 \\
\hline $76-80$ & 10 & 0,6 & 11 & 0,3 \\
\hline $80-84$ & 14 & 1,8 & 17 & 2,0 \\
\hline $84-88$ & 10 & 0,7 & 12 & 0,3 \\
\hline A & & & & 8 \\
\hline
\end{tabular}

Аналізуючи вертикальний розподіл ${ }^{137} \mathrm{Cs}$ в інших шарах грунтового розрізу, виявлено такі закономірності: у свіжих борах, починаючи із шару на глибині 1620 см відбувається різке зменшення вмісту ${ }^{137} \mathrm{Cs}$ відносно елювіального шару (12-16 cм); розподіл ${ }^{137} \mathrm{Cs}$ за шарами є більш рівномірний; на глибині 56-60 см знову спостерігалось значне зменшення питомої активності. Відзначені відмінності підтверджуються результатами однофакторного дисперсійного аналізу на $95 \%$-му довірчому рівні, де $\mathrm{F}_{\text {теор. }}>\mathrm{F}_{\text {прак. }} \mathrm{B}$ умовах свіжих суборів виявлено рівномірне зменшення питомої активності за шарами від 12-16 см до 44-48 см. Існування достовірної різниці між середніми значеннями питомої актив- ності ${ }^{137} \mathrm{Cs}$ між шарами підтверджуються однофакторним аналізом на $95 \%$-му довірчому рівні $-\mathrm{F}_{\text {факт. }}=60,5>$ $\mathrm{F}_{(8 ; 89 ; 0,95)}=2,1$. Починаючи зі шарів на глибині $52-56 \mathrm{~cm}$ питома активність істотно зменшується і не перевищує 20 Бк/кг. Отже, результати розподілу ${ }^{137} \mathrm{Cs}$ у мінеральній частині грунту демонструють зниження питомої активності грунту із глибиною. Враховуючи цей факт, провели регресійний аналіз залежності питомої активності ${ }^{137} \mathrm{Cs}$ у мінеральних шарах від глибини (рис. 1).

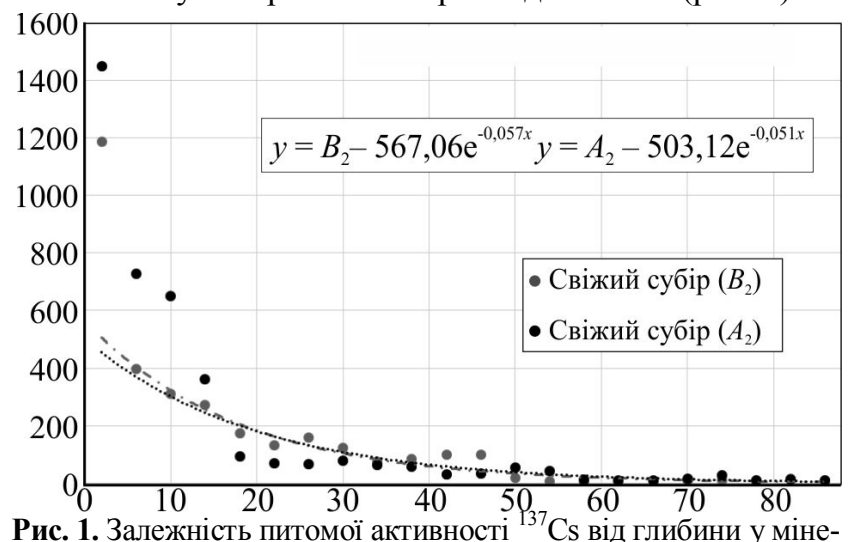

Рис. 1. Залежність питомої активності ${ }^{37} \mathrm{Cs}$ від глибини у мінеральних шарах грунту свіжих бору та субору

3 отриманих результатів можна стверджувати, що вертикальний розподіл питомої активності у мінеральних шарах грунту в обох досліджуваних типах лісорослинних умов має експоненціальну залежність. Рівняння залежності питомої активності ${ }^{137} \mathrm{Cs}$ від глибини має такий вигляд: $y=a \cdot \exp ^{(-b \cdot x)}$. Для питомої активності свіжого бору та субору коефіцієнт кореляції становить 0,91 та 0,90 відповідно, коефіцієнти значущості наближаються до нуля, що свідчить про високу достовірність зв'язку на 95 \%-му довірчому рівні. Отже, отриманні залежності $є$ тісними, а рівняння достовірними. Окрім цього, проаналізовано зміну експоненціальної залежності від різної глибини відбору зразків у грунтовому розрізі. Так, у мінеральних шарах грунту на глибині 0-12 см коефіцієнт кореляції для свіжих борів становить 0,92, а для свіжих суборів - 0,94; на глибинні 0-24 см - 0,97 i 0,95 та 0-32 см - 0,94 і 0,91 см відповідно. Отже, з отриманих результатів можна стверджувати, що основний вміст ${ }^{137} \mathrm{Cs}$ сконцентровано в 0-24 см мінеральному шарі грунту в обох досліджуваних типах лісорослинних умов.

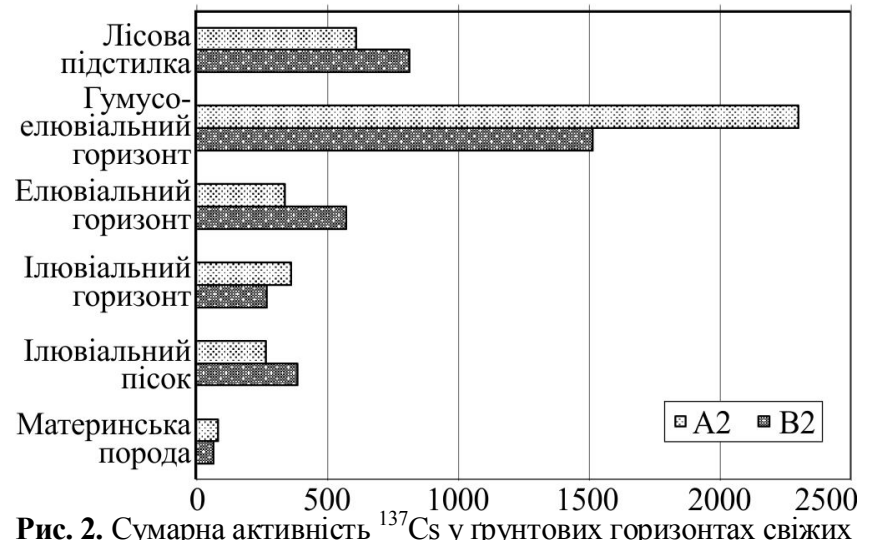
борів та суборів Українського Полісся, Бк/кг

Питома активність радіонукліду у тих чи інших шаpax грунту не передає дійсний його вміст, оскільки щільність лісової підстилки досить невелика відносно 
мінеральної частини грунту та й більш заглиблені шари останньої щільніші, ніж верхні. Досліджено розподіл сумарної активності ${ }^{137} \mathrm{Cs}$ у різних шарах грунтового профілю (рис. 2).

Отримані матеріали свідчать про те, що, незважаючи на значні рівні питомої активності ${ }^{137} \mathrm{Cs}$ у лісовій підстилці, частка сумарної активності всіх фракцій лісової підстилки у свіжих борах становить 15,4 \% від сумарного запасу радіонукліду у грунті, а у свіжих субоpax - 22,5 \%. Отже, матеріали свідчать, що лісова підстилка свіжого субору утримує більше ${ }^{137} \mathrm{Cs}$, ніж у свіжому бору (в 1,3 раза), що підтверджується однофакторним дисперсійним аналізом $-\mathrm{F}_{\text {факт. }}=40,1>$ $\mathrm{F}_{(1 ; 5 ; 0,95)}=7,7$.

Розподіл загальної активності ${ }^{137} \mathrm{Cs}$ у грунті свідчить про переміщення основної його кількості до мінеральної частини. Частка загальної активності радіонукліду у гумусово-елювіальному шарі свіжих борів і суборів становить 58,2 та 41,8 \% відповідно, це в 3,7 та 1,8 раза більше, ніж сумарна активність лісової підстилки. Існування достовірної різниці між середніми значеннями сумарної активності ${ }^{137} \mathrm{Cs}$ у гумусово-елювіальному шарі та лісовій підстилці підтверджується результатами однофакторного дисперсійного аналізу: свіжі субори $\mathrm{F}_{\text {факт. }}=757>\mathrm{F}_{(1 ; 5 ; 0,95)}=7,7$ та свіжі бори $-\mathrm{F}_{\text {факт. }}=688>$ $\mathrm{F}_{(1 ; 5 ; 0,95)}=7,7$. Окрім цього, встановлено існування достовірної різниці сумарної активності ${ }^{137} \mathrm{Cs}$ між гумусовоелювіальними горизонтами досліджуваних типів лісорослинних умов $\mathrm{F}_{\text {факт. }}=164>\mathrm{F}_{(1 ; 5 ; 0,95)}=7,7.3$ подальшим заглибленням спостерігається зменшення сумарної активності радіонукліду. Сумарна активність ${ }^{137} \mathrm{Cs}$ в елювіальному горизонті свіжих суборів становить 571 Бк, а свіжих борів - 338 Бк. В ілювіальному горизонті міститься 9,1\% від загальної активності ${ }^{137} \mathrm{Cs}$ у грунті свіжого бору та 7,4 \% у грунтах свіжих суборів; в ілювіальному піску - 6,7, 10,7\% та материнській породі 2,1 та 1,8\% відповідно. Сумарна активність ${ }^{137} \mathrm{Cs}$ у грунтовому розрізі від ілювіального горизонту до материнської породи становить 17,9\% у свіжих борах та 19,9 \% - у суборах. Оцінюючи загальний розподіл ${ }^{137} \mathrm{Cs}$ між двома типами лісорослинних умов, можна стверджувати, що основний вміст зосереджено в лісовій підстилці та гумусово-елювіальному горизонті свіжих борів - 73,6 \% та суборів - 64,3\%, до нижніх шарів грунтового розрізу (12-88 см) мігрувало 26,4 та $35,7 \%$ від загального запасу радіонуклідів.

Висновки. На підставі проведених досліджень можна зробити такі висновки:

1) У свіжих борах і суборах максимальні величини питомої активності ${ }^{137} \mathrm{Cs}$ виявлено у лісовій підстилці, 3 поступовим збільшенням цього показника від сучасного опаду до розкладеного шару. Сумарна активність всіх фракції лісової підстилки у свіжих борах становить 15,4 \% від сумарного запасу радіонукліду грунту, а у свіжих суборах $-22,5 \%$. У лісовій підстилці свіжого субору утримується більша активність ${ }^{137} \mathrm{Cs}$, ніж у підстилці свіжого бору (в 1,3 раза).

2) Частка сумарної активності радіонукліду в лісовій підстилці та гумусово-елювіальному горизонті свіжих борів становить 73,6 \% та суборів - 64,3\%. До нижніх (12-88 см) шарів мігрувало 26,4 та 35,7 \% від загально- го запасу радіонукліду у грунті. Частка загальної активності радіонукліду у гумусово-елювіальному шарі свіжих борів і суборів становить 58,2 та 41,8 \% відповідно.

3) У мінеральній частині грунту основний вміст ${ }^{137} \mathrm{Cs}$ виявлено у 0-4 см шарі гумусово-елювіального горизонту з подальшим поступовим зменшенням в інших горизонтах. Встановлено, залежність питомої активності ${ }^{137} \mathrm{Cs}$ у мінеральних шарах від глибини, яка має достовірний тісний експоненціальний зв'язок.

\section{Перелік використаних джерел}

Boiko, O. L. (2012). Rozpodil sumarnoi aktyvnosti Cs u lisovykh fitotsenozakh. Lisivnytstvo $i$ ahrolisomelioratsiia, 120, 87-94. [In Ukrainian].

Bondapenko, G. N., \& Kononenko, L. V. (1995). Rasppedelenie fopm nakhozhdeniia ${ }^{90} \mathrm{Sr}$ i ${ }^{137} \mathrm{Cs}$ po veptikalnym pochvennym pazpezam zony otchuzhdeniia AES. Ppoblemy Chopnobylskoi zony vidchuzhennia, 2, 176-185. [In Ukrainian].

Bulavik, I. M., \& Zhuchenko, T. A. (1992). Radionuklidy v elementakh lesnogo biogeotcenoza. Chernobyl 92. (3rd ed). Po itogam likvidatcii posledstvii avarii na Chernobylskoi AES, 4(1), 94-108. [In Russian].

Krasnov, V. P, Kurbet, T. V., Shelest, Z. M., \& Boiko, O. L. (2016). ${ }^{137} \mathrm{Cs}$ redistribution in time in wet bory and sugrudy soils in Forests of Ukrainian Polissia. Nuclear physics and atomic energy, 1(17), 63-68. [In Ukrainian].

Krasnov, V. P. (1998). Radioekolohiia lisiv Polissia Ukrainy. Zhytomyr: Volyn, 112 p. [In Ukrainian].

Krasnov, V. P., Kurbet, T. V., Davydova, I. V., Shelest, Z. M., \& Boiko, O. L. (2015). Vertykalnyi rozpodil sumarnoi aktyvnosti ${ }^{137} \mathrm{Cs} \mathrm{u}$ gruntakh lisiv Polissia Ukrainy. Scientific Bulletin of UNFU, 25(5), 123-129. [In Ukrainian].

Krasnov, V. P., Orlov, A. A., Buzun, V. A., et al. (2007). Prykladnaia radyoekolohyia lesa. Zhytomyr: Polissia, 680 p. [In Ukrainian].

Kulikov, I. V., Molchanova, I. V., \& Karavaeva, E. N. (1990). Radioekologiia pochvenno-rastitelnogo pokrova. Sverdlovsk.: UrANSSSR, 170 p. [In Russian].

Landin, V. P. (1993). Osoblyvosti radioaktyvnoho zabrudnennia lisiv Ukrainskoho Polissia. Lisivnytstvo $i$ ahrolisomelioratsiia, 86, 1016. [In Ukrainian].

Landin, V. P., Krasnov, V. P., Kurbet, T. V., Orlov, O. O., Savushchik, M. P., \& Davydov, M. M. (2011). Rezultaty radioekolohichnykh doslidzhen u lisovykh ekosystemakh Ukrainy, zabrudnenymy avariinymy vykydamy Chornobylskoi AES. Ahroekolohichnyi zhurnal, 1, 53-57. [In Ukrainian].

Perevolotckii, A. N., Bulavik, I. M., Perevolotckaia, T. V., et al. (2007). Osobennosti raspredeleniia ${ }^{137} \mathrm{Cs} \mathrm{i}{ }^{90} \mathrm{Sr} v$ pochve i nakopleniia drevesinoi i koroi sosny (Pinus sylvestrisL.) v razlichnykh usloviiakh mestoproizrastaniia. Radiatcionnaia biologiia. Radioekologiia, 4(47), 463-470. [In Russian].

Popupana, N. I., Nosko, B. S., \& Kuzmicheva, V. P. (1981). Polevoi opredelitel pochv. Kyiv: Urozhai, 321 p. [In Russian].

Shcheglov, A. I. (1999). Biogeokhimiia tekhnogennikh radionuklidov v lesnykh ekosistemakh. Moscow: Science, 268 p. [In Russian].

Shcheglov, A. I., Tikhomirov, F. A., Tcvetnova, O. B., Kliashtorin, A. L., \& Mamikhin, S. V. (1996). Biogeokhimiia radionuklidov chernobylskogo vybrosa $\mathrm{v}$ lesnykh ekosiste-makh evropeiskoi chasti SNG. Radiatcionnaia biologiia. Radioekologiia, 4(36), 469-478. [In Russian].

Siaskyi, S. S., \& Stetsiuk, M. H. (2001). Rozprydilennia radiotseziiu v edafichnomu seredovyshchi. Visnyk DAAU, 1, 148-149. [In Ukrainian].

Vedmid, M. M., \& Raspopina, S. P. (2010). Otsinka lisoroslynnoho potentsialu zemel. Kyiv: EKO-inform, 84 p. [In Ukrainian]. 


\section{СОВРЕМЕННОЕ ВЕРТИКАЛЬНОЕ РАСПРЕДЕЛЕНИЕ ЦЕЗИЯ-137 В ПОЧВАХ СВЕЖИХ БОРОВ И СУБОРОВ УКРАИНСКОГО ПОЛЕСЬЯ}

Проанализировано современное распределение ${ }^{137} \mathrm{Cs}$ в лесных почвах различных типов лесорастительных условий Украинского Полесья. Выявлены максимальные величины удельной активности радионуклида в лесной подстилке. По величине удельной активности ${ }^{137} \mathrm{Cs}$ слои лесной подстилки свежих боров и суборов можно разместить в порядке уменьшения: разложенный слой $>$ полуразложенный слой $>$ современный опад. Наибольшие значения удельной активности радионуклида в минеральной части почвы отмечены в 0-4 см слое гумусово-элювиального горизонта: в свежих борах этот показатель составлял $1450^{ \pm 36}$ Бк/кг, в свежих суборах $-1187^{ \pm 31}$ Бк/кг. С углублением в почву наблюдается постепенное уменьшение величин удельной активности ${ }^{137} \mathrm{Cs}$. Установлено следующее распределение суммарной активности ${ }^{137} \mathrm{Cs}$ в почвенных горизонтах свежих боров и суборов: в элювиальном - 8,5 и 15,8\% от общей активности радионуклида в почве; в иллювиальном 9,1 и 7,4 \%; в иллювиальном песке - 6,7 и 10,7 \% и материнской породе - 2,1 и 1,8\% соответственно. Общее суммарное содержание ${ }^{137} \mathrm{Cs}$ в лесной подстилке и гумусово-элювиальных горизонтах составляет в свежих борах 73,6\%, суборах $64,3 \%$. Долевое участие суммарной активности ${ }^{137} \mathrm{Cs}$ в лесной подстилке составляет $15,4 \%$ в свежих борах и $22,5 \%$ в свежих суборах. К нижним слоям почвенного разреза (12-88 см) мигрировало соответственно 26,4 и 35,7 \% от общего запаса радионуклида в почве.

Ключевые слова: распределение радионуклидов; лесные почвы; удельная активность ${ }^{137} \mathrm{Cs}$; суммарная активность; тип лесорастительных условий.

\section{V. Melnyk \\ Zhytomyr State Technological University, Zhytomyr, Ukraine}

\section{MODERN VERTICAL DISTRIBUTION OF CESIUM-137 IN THE SOILS OF FRESH BORS AND SUBORS OF UKRAINIAN POLISSIA}

The soil cover has accumulated ${ }^{137} \mathrm{Cs}$ and become the first link in the chain of migration of radionuclides to other components of forest ecosystems. The modern distribution of ${ }^{137} \mathrm{Cs}$ in forest soils of different types of forest conditions of Ukrainian Polissya is analysed. Selection of soil samples was carried out on layers of $4 \mathrm{~cm}$ in thickness in a tenfold repetition with a special sampler, at depths up to $88 \mathrm{~cm}$. The division of forest litter was carried out according to the degree of mineralization - modern precipitation, semi-decomposed layer and decomposed layers. It is found that the maximum values of the specific activity of radionuclide in the forest litter. The layers of the forest litter of fresh bors and subors can be placed in the following ascending order: decomposed layer $>$ semi-decomposed layer $>$ modern precipitation by the magnitude of the specific activity ${ }^{137} \mathrm{Cs}$. The highest values of specific activity in the mineral part of the soil were observed for a $0-4 \mathrm{~cm}$ layer of the humus-eluvial horizon: in fresh bors, they were $1450^{ \pm 36} \mathrm{~Bq} / \mathrm{kg}$, in fresh subors $-1187^{ \pm 31} \mathrm{~Bq} / \mathrm{kg}$. With deepening in the soil, a gradual decrease in the specific activity of ${ }^{137} \mathrm{Cs}$ is observed. In both types of forest conditions, the movement of a significant amount of ${ }^{137} \mathrm{Cs}$ to the mineral part of the soil was detected. It was found that the distribution of the total activity of ${ }^{137} \mathrm{Cs}$ in the ground horizons of fresh bors and subors was as follows: in eluvial $-8.5 \%$ and $15.8 \%$ of the total activity of radionuclide in the soil; in illuvial $-9.1 \%$ and $7.4 \%$; in the iluvial sand $-6.7 \%$ and $10.7 \%$, and in the mother stock $-2.1 \%$ and $1.8 \%$ respectively. The total summary content of ${ }^{137} \mathrm{Cs}$ in the forest litter and the humus-eluvial horizon is in fresh bors $-73.6 \%$, in subors $-64.3 \%$. The share of total activity of ${ }^{137} \mathrm{Cs}$ in the forest litter is $15.4 \%$ in bors $\mathrm{S}$ and $22.5 \%$ in fresh subors. Of the total stock of radionuclide in the soil to the lower layers of the soil $(12-88 \mathrm{~cm})$ migrated respectively $26.4 \%$ and $35.7 \%$. The received materials are confirmed by one-factor analysis at $95 \%$ confidence level. For both studied types of forest plant conditions we have discovered closely exponential dependence of the concentration of ${ }^{137} \mathrm{Cs}$ in the mineral layers of the soil on depth.

Keywords: radionuclides distribution; forest soils; specific activity of ${ }^{137} \mathrm{Cs}$; total activity; forest site conditions; forest floor. 